Ankara Üniversitesi

SBF Dergisi,

Araştırma Makalesi

Cilt 74, No. 3, 2019, s. 983 - 1001

DOI: $10.33630 /$ ausbf.569746

\title{
DISPOSSESSION AND DEVELOPMENT IN THE NEOLIBERAL ERA`
}

\author{
Dr. Öğr. Üyesi Burak Gürel \\ Koç Üniversitesi \\ İnsani Bilimler ve Edebiyat Fakültesi \\ ORCID: 0000-0002-1666-8748
}

\begin{abstract}
Based on a detailed review of the existing literature, this article makes four arguments regarding the dispossessory effects of development projects in the neoliberal era. First, it redefines "accumulation by dispossession" as the state's transfer of lower-class people's small-scale private property or common property over land, water, and other resources to capital through extra-economic and/or economic coercion. In doing so, the paper stresses the need to clearly distinguish the state's deliberate manipulation of the market for dispossessory purposes from the centralization of capital through market competition. Second, it suggests that while the goal of expanding capitalist production shaped dispossessory practices in the era of national developmentalism, the link between production and dispossession has been less direct and relatively weaker in the neoliberal era. Hence, due to the rapid development of labor-saving technology and increasing significance of the real estate sector, capital prioritizes the land and natural resources of the lower-class people over the exploitation of their labor. Third, international development institutions like the World Bank depoliticize development in order to naturalize and legitimize dispossession. Finally, this paper points to the potentials of and challenges to possible alliances of workers' movements and popular struggles against dispossession.
\end{abstract} Resistance

Keywords: Neoliberalism, Developmentalism, Accumulation by dispossession, Proletarianization,

\section{Neoliberal Dönemde Mülksüzleştirme ve Kalkınma}

\section{Öz}

Ayrıntılı bir literatür taramasına dayanan bu makale neoliberal dönemde uygulanan kalkınma projelerinin mülksüzleştirici etkilerine ilişkin dört temel argüman sunuyor. Birincisi, "mülksüzleştirme yoluyla birikim" kavramı alt sınıfların kontrolündeki (küçük ölçekli özel mülkiyet veya ortak mülkiyet statüsündeki) toprak, su ve diğer kaynakların devlet tarafindan ekonomi-dışı ve ekonomik zor yoluyla sermayeye transferi olarak yeniden tanımlanmalıdır. Bunu yaparken, devletin mülksüzleștirme hedefiyle piyasayı manipüle etmesi ile piyasa rekabeti yoluyla sermayenin merkezileşmesi arasında net bir ayrım yapılmalıdır. İkincisi, kapitalist üretimi genişletme hedefinin mülksüzleştirme pratiklerini şekillendirdiği ulusal kalkınmacı dönemden farklı olarak neoliberal dönemde üretim ile mülksüzleştirme arasındaki ilişki daha dolaylı ve zayıftır. Emek tasarrufu yapan teknolojilerin hızlı gelişimi ve emlak sektörünün giderek önem kazanması nedeniyle sermaye alt sınıfların elindeki topraklara ve doğal kaynaklara erişimi onların emeğini sömürmeye nazaran daha öncelikli görmektedir. Üçüncüsü, Dünya Bankası gibi uluslararası kalkınma kurumları mülksüzleştirmeyi doğallaştırmak ve meşrulaş̧ırmak için kalkınma kavramını depolitize etmektedirler Son olarak, bu makale işçi hareketleri ile mülksüzleştirme karşıtı halk mücadeleleri arasındaki ittifakların potansiyeline ve önündeki engellere işaret ediyor.

Anahtar Sözcükler: Neoliberalizm, Kalkınmacılık, Mülksüzleştirme yoluyla birikim, Proleterleşme, Direniş

* Makale geliş tarihi: 02.12.2017

Makale kabul tarihi: 15.12.2018

Erken görünüm tarihi: 24.05.2019 


\section{Dispossession and Development in the Neoliberal Era*}

\section{Introduction}

Presenting all past histories as a prelude to modernity is one of the pillars of modernization theory's near-hegemony in the social sciences. In this framework, history is "simply the overdetermined precedents leading to modernity," and modernity is "all the names of history" (Harootunian, 2000: ix). This deceptive reduction of all historical experiences to a unilinear/teleological narrative can best be observed in the definition of "development." Modernization theory promises the poor people of the Global South that if they follow the same developmental path taken long ago by Western countries, they will surely reach a similar level of development. By simply dismissing the contradictory and uneven character of capitalist development, it assumes that capitalism "will eventually lead to even development" (Harootunian, 2000: xv). In this sense, modernization theory is an active and purposeful denial of the uneven and combined character of capitalist development: ${ }^{1}$

The naturalization of history empties history of its content. The historical conditions that would explain the 'lead' of some countries over others cannot enter into the argument, since the 'laws of development' are supposedly the same for all, and 'win their way through with iron necessity'; what happened in Europe between the eighteenth and nineteenth centuries must therefore be reproduced elsewhere. Not only does this bracket out the effects of conquest, colonization, the slave trade, the dismantling of craft production in India, the breaking up of social structures, and so on; it also presents things as if the existence of industrial countries did not radically alter the context in which candidates for industrialization have to operate. The world is conceived not as a structure in which each element depends upon the others, but as a collection of formally equal 'individual' nations. One recognizes here the ideology of equal opportunities and the 'self-made man' (Rist, [1997] 2008: 74-75).

* I would like to thank the reviewers for Ankara University SBF Journal and Eylem Taylan for their helpful comments and suggestions.

1 On the concept of uneven and combined development see Anievas and Nişancioğlu, 2015; Trotsky, [1932] 2008; van der Linden, 2007. 
The discourses and practices of international institutions like the World Bank, the United Nations Development Program, the Asian Development Bank, and the Asian Infrastructure Investment Bank, as well as the development institutions operating at the national level, reproduce the illusion of equal opportunity for all nations. One should be careful not to view capitalist developmentalism as discourse only, as it plays a concrete role in opening up new spaces for capital accumulation and expanding state power, as well as in silencing different political alternatives seeking to overcome inequality within and between nations.

Based on a review of some of the exemplary theoretical and empirical analyses of development policy, accumulation by dispossession, and popular struggles against the dispossessory effects of development projects in the neoliberal era, this article makes four arguments concerning the dispossessory effects of neoliberal development projects. First, it engages with recent debates over the conceptual boundaries of "accumulation by dispossession" in order to redefine it as the state's transfer of lower-class people's small-scale private property or common property (over land, water, and other resources) to capital through the deployment of extra-economic and/or economic coercion. Second, it argues that while productive concerns such as industrialization and infrastructure construction shaped the politics of dispossession in the era of national developmentalism, the link between production and dispossession is more indirect and relatively weaker in the neoliberal era. Third, this paper shows how the discourses of international institutions depoliticize the question of development in order to legitimize dispossession. Finally, it points to the potentials of and challenges to possible alliances of workers' movements and popular movements against dispossession.

This paper consists of five sections. The first section defines the paradigm changes in development policy since the end of World War II. The second section redefines the concept of accumulation by dispossession and situates it within the changing development paradigms. The third section focuses on the depoliticizing dynamics of neoliberal developmentalist discourse. The fourth and fifth sections discuss exemplary cases of accumulation by dispossession and popular resistances against them in the early 2000s. Finally, the concluding section summarizes the main findings of this study.

\section{Paradigmatic Changes in Development Policy}

Existing scholarship studies the history of development paradigms after World War II in the context of three main periods: national developmentalism (from 1945 to the late 1970s); neoliberalism, or the "Washington Consensus" 
(from the late 1970s to the late 1990s); and the post-Washington Consensus (since the late 1990s).

The era of national developmentalism witnessed the competition of different developmentalist projects, including the capitalist path promoted by the USA, the non-capitalist path promoted by the Soviet Union, and "Third Worldism," which included diverse (capitalist, non-capitalist, and mixed economy) paths with a shared emphasis on non-aligned and relatively autonomous development, symbolized by the Bandung Conference in $1955 .{ }^{2}$ Despite significant differences between these paths, national developmentalism represented a broad consensus on the imperative of increasing the per capita national income through rapid industrialization and agricultural modernization. Rapid improvements in education, healthcare, and hard infrastructure (such as transportation, electricity, and irrigation) were deemed necessary to boost the per capita GDP. A strong emphasis on the state's role in economic development was a distinguishing trait of national developmentalism. Even the capitalist path sponsored by the USA (and the Bretton Woods institutions closely linked with American interests, the International Monetary Fund [IMF], and the World Bank [WB]) allowed for significant state intervention. Capitalist states of poor countries that had recently won national independence were believed to have the right to play an imperative and active role in the development of public infrastructure and services, in the promotion of infant industries through import substitution, and in the maintenance of by-and-large self-sufficient food production through farm subsidies and trade protection. Although the USA-led path cherished international trade and foreign direct investment, it also acknowledged the nation states' right to regulate the flows of financial capital across national borders. The scope of state intervention in the economy was obviously extensive in the non-capitalist and Third Worldist versions of national developmentalism.

Under the pressure of revolutionary waves and the resulting formation of non-capitalist regimes spanning from Eastern Europe to East Asia, capitalist states gave significant concessions to the working class in the form of formal and stable jobs, pensions, the right to unionize, and free healthcare and education. In fact, regime competition during the Cold War led to significant welfare expansion on both sides of the Iron Curtain (Obinger and Schmitt, 2011). Of course, differences in terms of the balance of power between capital and labor and financial capacity of the state led to significant international variation of welfare expansion.

2 For a comprehensive survey of different forms of national developmentalism in the post-WWII era see Rist, [1997] 2008: 69-92. 
In response to the world economic crisis of the mid-1970s (characterized by a prolonged decline of profitability across the world, including in advanced economies), a rapid paradigm shift from national developmentalism to neoliberalism took place. Due to the USA's direct influence on the formulation and global promotion of neoliberalism (especially through the IMF and WB), the neoliberal project is also called the "Washington Consensus" (WC). Neoliberal policies took back some of the concessions previously given to workers. Early neoliberal policies in the late 1970s and 1980s weakened the right to unionize, suppressed wages, raised the retirement age, and cut various social benefits. Such changes were implemented in many different countries (including Chile under Pinochet, Britain under Thatcher, Turkey under Evren and Özal, and the USA under Reagan).

Beyond the assault against labor, neoliberalism represents a paradigm shift in economic development policy. According to the neoliberal development doctrine, "getting the prices right" (i.e., allowing the free market to function without significant state intervention) is the most effective way to achieve sustained economic growth. Through the privatization of state-owned enterprises, trade liberalization, deregulation of financial flows across national borders (through opening capital accounts), an end to infant industry promotion, and cuts to agricultural subsidies, neoliberal policies have significantly curtailed state intervention in the economy. Although state involvement in infrastructure construction and the provision of healthcare and education services was not totally discarded, states were encouraged to allow greater private sector involvement in these areas.

The geography of neoliberalism was not restricted to countries that were originally part of the USA-led camp. The transition to capitalism in the formerly non-capitalist world (such as Eastern Europe, the Soviet Union, China, and Vietnam) dramatically expanded the geographical scope of neoliberalization in the 1990s. This dramatic change also led to the neoliberalization of India and other former (Asian and African) advocates of the Bandung framework of relatively autonomous development, which promoted heavy state intervention (Harvey 2005).

In the late 1990s and early 2000s, the neoliberal project began to unravel. Refuting the neoliberal claim that privatization and deregulation increase the rate of economic growth, median per capita income growth in developing countries declined from 2.9\% in 1960-1979 to 0\% in 1980-1998 (Easterly, 2001, 135). And defying the neoliberal belief that illiberal economic policies were responsible for persistent poverty, the share of the world population living on less than $\$ 1$ per day declined quite slowly, from $28.3 \%$ in 1987 to $23.2 \%$ in 1999. Interestingly, the rate of poverty decline in the same period becomes much smaller (from $28.3 \%$ to $25 \%$ ) when China is excluded (Fischer, 2003: 8). 
In addition to major failures in economic growth and poverty eradication, severe economic crises in the developing world (including the Asian economic crisis in 1997, the Russian crisis of 1998, the Argentinian crisis of 2001, and Turkish crises in 1994, 1999, and 2001) further weakened the belief in neoliberalism's promise of stable growth. Furthermore, academic and policy literatures acknowledged that major countries with respectable growth performance and strong protection from financial shocks (including China, India, and Malaysia) diverged from the neoliberal orthodoxy in important waysnamely, in a higher degree of state intervention in the economy, incomplete privatization, and relatively stronger controls over short-term flows of financial capital. This awareness also contributed to neoliberalism's loss of credibility. At the same time, academic and policy circles began to read the experience of successful late industrialization in South Korea and Taiwan as a consequence of national developmentalism and criticized earlier interpretations that presented these experiences as proof of the neoliberal creed. Finally, mass protests against neoliberal globalization across the world in the early 2000s also contributed to the unravelling of neoliberalism (Öniş and Şenses, 2005: 265-274).

The crisis of neoliberalism paved the way for a paradigm change in development thinking from the Washington Consensus to the "Post-Washington Consensus" (PWC). The latter term, coined by former chief economist of the World Bank Joseph Stiglitz (1998), was later adopted by many development scholars. ${ }^{3}$ Unlike the previous change (from national developmentalism to neoliberalism), the transition from the WC to the PWC was a "paradigm expansion" rather than a "paradigm shift" because the latter maintained the former's "neoliberal-globalist core" (Güven, 2018: 395) while incorporating an institutionalist perspective (giving the state a greater economic role) and new priorities (such as greater emphasis on decreasing poverty and reducing income and gender inequalities) (Güven, 2018: 396; Öniş and Şenses, 2005: 277).

An early sign of this paradigm expansion was The World Development Report 1997, which declared: "development requires an effective state, one that plays a catalytic, facilitating role" (World Bank 1997, cited in Güven, 2018: 395). Instead of completely rejecting state involvement in the economy as the WC did, the PWC recommended the use of "market-like mechanisms" to increase the competition among and thereby increase the efficiency of state bureaucrats. Similarly, contrary to the WC's "one-size-fits-all" approach towards privatization, the PWC acknowledges the opening of state-owned enterprises to competition with the private sector (rather than outright privatization) as a legitimate policy in certain contexts (Öniş and Şenses, 2005: 276). The world

3 For useful accounts of the Post-Washington Consensus see Öniş and Şenses, 2005; Güven, 2018. 
economic crisis which began in 2008 has deepened the shift towards the PWC. The most recent manifestation of this shift is the IMF's recent declaration that tax cuts for the wealthy do not assist economic development, a dramatic reversal of the "trickle down" orthodoxy it advocated for many decades (Elliott and Stewart, 2017).

Finally, although the neoliberal core of the PWC does not tolerate the return to the welfare state of the post-WWII period, neoliberal institutions, especially the World Bank, have increasingly stressed the need for expanding (in-cash and in-kind) social assistance in order to contain political unrest and mobilize the political support of the poor (van Gils and Yörük, 2017: 114). In this sense, the shift from the WC to the PWC largely corresponds to the shift from orthodox neoliberalism to "social neoliberalism" (Dorlach 2015; Güven, 2016; Öniş, 2012).

\section{Situating Dispossession in Development Paradigm Changes}

Dispossession of small-scale producers (such as peasants and artisans) from the means of production has been an integral trait of capitalist development. In response to Adam Smith, who asserted that the long-term savings of frugal entrepreneurs provided the initial capital invested in first modern industries, Karl Marx argued that the primary (primitive) capital accumulation was based on the dispossession of the peasantry by force:

The spoliation of the Church's property, the fraudulent alienation of the state domains, the theft of the common lands, the usurpation of feudal and clan property and its transformation into modern private property under circumstances of ruthless terrorism, all these things were just so many idyllic methods of primitive accumulation. They conquered the field for capitalist agriculture, incorporated the soil into capital, and created for the urban industries the necessary supplies of free and rightless proletarians (Marx, [1867] 1976: 895).

Marx warned that the dispossession of the peasantry "assumes different aspects in different countries, and runs through its various phases in different orders of succession, and at different historical epochs." In the European colonies, primitive accumulation progressed through the dispossession of peasantry from land, expansion of the use of various types of unfree labor, and plunder of mineral resources:

The discovery of gold and silver in America, the extirpation, enslavement and entombment in mines of the indigenous population of that continent, the beginnings of the conquest and plunder of India, and the conversion of 
Africa into a preserve for the commercial hunting of blackskins, are all things which characterize the dawn of the era of capitalist production. These idyllic proceedings are the chief moments of primitive accumulation [...] These methods depend in part on brute force, for instance the colonial system. But they all employ the power of the state, the concentrated and organized force of society, to hasten, as in a hothouse, the process of transformation of the feudal mode of production into the capitalist mode, and to shorten the transition (Marx, [1867] 1976: 915-916).

For Marx, continuous reinvestment of profits into expanded reproduction created a self-sustaining dynamic and gradually reduced the scope of and need for primitive accumulation. In this sense, primitive accumulation is "the prehistory of capital" (Marx, [1867] 1976: 875).

Two influential works of David Harvey, The New Imperialism (2003) and A Brief History of Neoliberalism (2005), offer a different conceptualization of dispossession. In contrast to Marx's understanding of primitive accumulation as the prehistory of capital, Harvey suggests that "accumulation by dispossession" has been a permanent characteristic of capitalism (Harvey, 2003: 176). For Harvey, contemporary primitive accumulation is fairly broad in scope:

These include the commodification and privatization of land and the forceful expulsion of peasant populations [...]; conversion of various forms of property rights (common, collective, state, etc.) into exclusive private property rights (most spectacularly represented by China); suppression of rights to the commons; commodification of labour power and the suppression of alternative (indigenous) forms of production and consumption; colonial, neocolonial, and imperial processes of appropriation of assets (including natural resources); monetization of exchange and taxation, particularly of land; the slave trade (which continues particularly in the sex industry); and usury, the national debt and, most devastating of all, the use of the credit system as a radical means of accumulation by dispossession (Harvey, 2003: 176).

Another important claim of Harvey is that the neoliberal era "has seen a shift in emphasis from accumulation through expanded reproduction to accumulation by dispossession." In other words, accumulation by dispossession became "the dominant form of accumulation relative to expanded reproduction" (Harvey, 2003: 153, 176).

In much of the still-expanding literature on the relevance of Harvey's theory of accumulation by dispossession, several arguments seem noteworthy in reaching a complete understanding of neoliberal developmentalism. First, although Harvey is justified in pointing to the continuing significance of accumulation by dispossession, his definition of the concept is too broad and therefore imprecise. For instance, the workers of state-owned enterprises were 
not outside capitalist social relations before privatization. They were proletarians compelled to sell their labor power for survival from the very beginning. Hence, enterprise privatizations worsen their living conditions (through layoffs and increasing precarity) without changing their proletarian status. Also, in many cases of privatizations of public services, "the service continues to be on the basis of need, and is largely or wholly funded out of general taxation," which helps explain "why the share of public expenditure in national income has changed so little in the advanced capitalist economies" before and after neoliberalization (Ashman and Callinicos 2006: 122). It should also be noted that the share of public expenditure in national income has either remain unchanged or has increased in many of the less developed countries, including Turkey. Moreover, Harvey problematically conflates the processes of dispossession, capitalist competition, and centralization of capital:

The beating out by agribusiness of family farms - who have already been living and dying by maximising profits- is an all-too-familiar aspect of capitalist competition. It is hard to fathom why Harvey would want to assimilate this to accumulation by dispossession any more than he would the destruction of family businesses (small or large) by giant corporations; likewise for the loss by Enron workers of their pensions along with their jobs when the firm went out of business. It deprives accumulation by dispossession of its substance (Brenner, 2006: 100-101).

In his response to this critique, Harvey acknowledges that his definition is too broad:

Brenner is probably right to complain that I inflate the idea somewhat. We agree on relations with precapitalist forms (like the ejidos in Mexico). The dispossession of family farms in the US may be better understood in terms of the normal transfers of wealth and power that occur through the concentration and centralisation of capital. I am not so sure, however, when it comes to the use of eminent domain to take over housing in high-value locations for the benefit of developers and the big chain stores (Harvey, 2006: 165).

Scholars agreeing with Harvey on the contemporary relevance of accumulation by dispossession discuss ways of defining the concept with greater precision. Michael Levien (2012) proposes to define accumulation by dispossession as the coercive acquisition of land and other resources by the capital and state. Like Marx, Levien considers extra-economic coercion to be the main criterion of dispossession. On the other hand, Levien rejects Marx's notion of dispossession as the prehistory of capital and agrees with Harvey that capital's continuous need for cheap access to land, water, and other resources makes dispossession an indispensable characteristic of capitalism. As Derek Hall (2013: 1593 ) notes, while Levien's intervention is useful in reaching conceptual clarity, 
"there may be circumstances in which a dichotomous conception of economic and extra-economic means of accumulation [...] will be difficult to maintain." For instance, without beating, arresting, or imprisoning them, states can compel peasants to sell their land cheaply and to join the proletariat through manipulating the level of tariffs, prices, subsidies, taxes, interest rates, and public investment (Hall, 2013: 1593; Vijayabaskar and Menon, 2018). Similarly, states can use deliberate disinvestment in infrastructure as a method of overcoming resistance against the gentrification of urban slums. The distinction between the dispossessory practices of the state and market competition is an important one. In the first case, states deliberately manipulate the market in order to transfer property from small peasants or lower-class homeowners to large companies. In the second case, large-scale capital drive small-scale producers out of the market.

Furthermore, although accumulation by dispossession leads to proletarianization by creating a propertyless mass dependent on wage labor for survival, there is no reason to view this outcome as the original purpose of dispossession. In many cases of dispossession, capital only needs the land and resources of the people but does not need their labor power (Hall, 2013: 1596; Li, 2011: 286; Levien, 2012: 938; Sassen, 2010: 23). This has been an important trait of dispossession since earlier periods of capitalism but has gained greater significance alongside the rapid development of labor-displacing technology and real estate expansion across the world.

I therefore define "accumulation by dispossession" as the transfer of smallscale private property or common property (over land and natural resources) from lower-class people to capital for various productive or speculative purposes through the state's deployment of extra-economic and/or economic coercion. It is obviously difficult to track the existence of the state's deliberate economic coercion and to distinguish it from the centralization of capital through market competition. It is also difficult to measure the degree of such coercion. Nevertheless, given its importance in altering the balance of power between the dispossessory dynamics of capital and the defenders of small private property and/or common property, scholarship on dispossession should define the economic coercion variable as precisely as possible.

Finally, Harvey's contention that accumulation by dispossession in the neoliberal era became more central than expanded reproduction is problematic. Given that commodities and capital still predominantly flow in a North-North direction (between advanced capitalist countries) and that the share of wage laborers within the entire labor force has grown across the world, there is no empirical ground to support Harvey's claim (Ashman and Callinicos 2006: 124129; Bailey, 2014-15). This problem notwithstanding, Harvey's attempt at historically analyzing the comparative weight of accumulation by dispossession and expanded reproduction is certainly useful in reaching a more accurate 
periodization of capitalist development. Harvey's attempt at linking the crisis of profitability in the mid-1970s to the attempts at restoring profits with or without employing wage labor is also notable. Inspired by Harvey's attempt, Jean Batou (2015: 31-32) formulates a hypothesis which informs a broader research agenda:

I believe it is possible to show a pattern of cyclical alternation between phases of heightened accumulation by dispossession (and centralization of capital) and phases of accumulation by expansion of wage labor. By and large, the former coincides with the long waves of stagnation, whereas the second relates to the long waves of accelerated growth in the capitalist economies. Each of these phases corresponds to a particular imbrication of the different modalities of accumulation. That is why their comparative study over the long run can contribute to a better understanding of the global development of capitalism.

Studying the historical transformation of the relationship between accumulation by dispossession and expanded reproduction might also explain their historical changes. While these two types of accumulation were closely linked in the era of national developmentalism, their relationship has been less direct and relatively weaker in the neoliberal era. As Levien notes, dispossession served "state-led industrialization and the accompanying infrastructural projects" in the Nehru era, the golden age of national developmentalism in India. In the neoliberal era, however, "industrial development corporations have been increasingly acquiring land outside of industrial areas for all kinds of private initiatives," including "luxury housing, golf courses, hotels and shopping malls" (Levien, 2012: 945). Differences between the two regimes of dispossession have shaped anti-dispossession politics in significant ways:

Whereas the developmentalist regime of dispossession for state-led projects of productive industrial transformation had significant legitimacy in the Nehruvian era, as people were asked to sacrifice for the greater good of "the nation," the neoliberal regime of dispossession, in which the state has become a mere land broker for increasingly real estate-driven private capital, is proving much less persuasive. With Nehruvian discourses of social justice and state-led development still retaining some purchase, the difficulty of justifying the expropriation of land from small farmers and transferring them to large, and sometimes foreign, corporations for increasingly real estate-driven projects no doubt helps to explain, if not the emergence of anti-dispossession movements, then the unprecedented public support and policy traction that they have gained in the last five years (Levien 2013: 361).

This framework also helps explain the reasons behind the strong opposition to dispossessory attempts in the cases discussed below. Finally, the paradigm expansion from the orthodox neoliberalism of the Washington Consensus to the social neoliberalism of the Post-Washington Consensus 
answers to capital's need to govern the unemployed (who are either dispossessed from land or laid off from jobs), whose labor capital does not need for the foreseeable future. The urgency of containing the poor has led institutions like the World Bank to adopt an increasingly flexible approach toward development projects. For instance, in Egypt,

\begin{abstract}
The proletariat of old had been created when rural and urban freeholders were set free from their autonomous relations to the means of production. Now the proletariat was being set free from its subsumption to capital and recreated as microentrepreneurs [...] National economy was being dismantled by structural adjustment policies [...] that were being enforced by those same [International Financial Organizations] who wanted to empower the poor through debt and microenterprise. Indigenous economic practices of the poor had lain in the remote margins of modernist images of national economy. Now those practices were being dusted off to assume central place in a new political economy of Egypt (Elyachar, 2005: 26-27).
\end{abstract}

In short, "social neoliberalism" aims to alleviate poverty created by orthodox neoliberalism during the 1980s and 1990s.

\title{
3. The Depoliticization of Development
}

Existing critical development scholarship shows that international institutions often tend to distort the political nature of crucial problems by representing them as non-political issues which simply demand expert knowledge and intervention. Depoliticization takes place in two ways. First, "political and structural causes of poverty are systematically erased" (Ferguson, 1990: 66). Despite the obvious fact that the problem of poverty stems from each region's historically-specific integration with world capitalism and the colonial past, international agencies insist on adopting each nation-state as their unit of analysis and openly disregard the context of world capitalism (Ferguson, 1990: 60). As James Ferguson (1990: 36) notes, this logic becomes absurd when considering a country like Lesotho, where "all determinants of economic life lie outside of the national boundaries." Michael Goldman suggests that by insisting that "there is no connection between increased poverty in the South and increased wealth accumulation in the North," international institutions actually promote a nationally narrow-minded explanation of economic backwardness and poverty (Goldman, 2005: 21). Similarly, in her study of micro-finance projects in Cairo funded and coordinated by the World Bank and the U.S. Agency for International Development, Julia Elyachar (2005: 12) notes that these projects "produced a widespread sense that what had failed was something specific to Egypt - the 
youth were lazy, the officials were corrupt, the banks were too rigid, and marketing had been neglected. It was not the market that was flawed - Egypt was flawed."

By dismissing the close connection between underdeveloped countries and the world economy, institutions like the World Bank jump to the conclusion that "poverty appears as a result of not yet having been introduced to the modern world" (Ferguson, 1990: 56). In other words, the promise of even capitalist development becomes a "necessary ideological claim to justify unlimited expansion and the production of surplus and excessive desire" (Harootunian, 2000: xxii). The legitimization of practices such as the privatization of natural resources "requires the violence of abstraction and the denial of colonial-imperial history to derive such a simplified narrative" (Goldman, 2005: 270). The World Bank and other international institutions often legitimize their policies through "violent reconstruction" of illusionary data (Ferguson, 1990: 45-46).

Once all problems are deemed technical ones, their solutions are expected to result from development projects designed by "experts." The definition of "target populations" as "in need of development" normalizes the "asymmetric relations between experts and beneficiaries" (Goldman, 2005: 170). The people are expected to see international agencies and ruling elites not as representatives of specific economic and political interests, but as technicians seeking to improve the living standards of the poor. Hence, "issues involving the political character of the state and its class basis" become invisible in the "development" paradigm: "The World Bank Report [...] makes literally no mention of politics. In the extreme 'development' representation, the state has no interests except 'development," and thus "a government of entrenched elites becomes an instrument of empowering the poor" (Ferguson, 1990: 65-66). Therefore, radical political alternatives that would challenge existing power relations are silenced by the development paradigm:

\begin{abstract}
An analysis which suggests that the causes of poverty in Lesotho are political and structural (not technical and geographical), that the national government is the part of the problem (not a neutral instrument for its solution), and that meaningful challenge can only come through revolutionary transformation in South Africa has no place in "development discourse" simply because "development" agencies are not in the business of promoting political realignments or supporting revolutionary struggles (Ferguson, 1990: 69).
\end{abstract}

In short, "depoliticization" should not be read as the depoliticization of all actors, regardless of their class and social bases. On the contrary, depoliticization (the task of the "anti-politics machine") is an effective political tool used by state elites and institutions of global capitalism in order to implement their politics of "development" without significant resistance. In this sense, one Lesothon 
villager's caustic note that "it seems that politics is nowadays nicknamed 'development"' (Ferguson, 1990: 247) reveals how depoliticization works.

\section{Dispossession through Development Projects}

As discussed above, development projects often involve the dispossession of people from land and other resources. Ferguson is therefore right to note that "the development of capitalism and the elimination of poverty are, if not positively antithetic (as many neo-Marxists argue), at any rate identical" (1990: 55). Harootunian (2004: 121-122) expands upon this point:

Capitalism is not a "system of development" but rather an abstract tendency and an historical reality that produces capital and augments its unlimited expansion. [...] The logic of capitalist expansion, knowing only the limits of capital itself, can never really imply development because it will always generate unevenness and forms of unequal exchange. Capitalism, for example, is never capable or interested in developing full employment or producing equality in income distribution since expansion is always powered by the pursuit of profit for the state and companies that own them as private property.

Ferguson similarly diagnoses the dangerous misunderstanding of distinct and contradictory definitions of development (1990: 55). However, he sometimes seems to confuse the failure of development projects and the failure of capitalist transformations. For instance, Ferguson argues that both the champions and critics of development projects share the notion that "a rural development project does in fact - for better or worse- bring about some sort of 'development,' some sort of economic transformation toward a well-defined end point" (1990: 15). Although it is possible to find many cases (including his case study of Lesotho) supporting the argument that no real economic transformation has been achieved as a result of development schemes, it would be premature, based only on cases of total failure, to jump to the conclusion that there is no capitalist transformation. Without attaching any overly-positive meaning to the concept of development, the entire history of capitalism (including colonialism) can be read as a great transformation of economic, social, and cultural realms (after all, what else is "capitalist development"?). Of course, this transformation has never finished at "a well-defined end point," as correctly pointed out by Ferguson (or has never achieved even capitalist development, as stated by Harootunian), but it seems obvious that capitalism has brought about a global transformation. The same is true for development projects, regardless of some cases of total failure. In this sense, Goldman cites the "interplay between the project of development" (Goldman, 2005: 150) and "uneven and combined capitalist development" (2005: 260) as the main sources of the search for and exploitation of new sites 
for capital accumulation through dispossession.

Ferguson examines the dispossession of local people through "development" practices in Thaba-Tseka in 1975 (1990: 243), an example which supports the argument that development projects have the potential to bring real transformation. Ferguson's account delineates that the failure of "development" projects does not mean the absence of potential capitalist transformation (1990: 15). In fact, he demonstrates that peasant resistance against dispossession attempts was the driving force underlying the Thaba-Tseka Project's failure to transform the region (1990: 244). In addition, Ferguson shows how the projects' goals of "conservation," "centralization," and "improvement" were closely "linked to land alienation and control" throughout the African continent (1990: 264). Goldman takes the "accumulation by dispossession" argument further by examining contemporary cases of dispossession. He offers the example of the creation of eco-zones in Laos, which shifted "the rights and access to the forests' vast natural resources from forest-dwelling communities to the energy, conservation, and tourism industries" (2005: 213). He also shows how "water conservation" programs promoted by international institutions lead to water privatization, increasing both water prices and the dependency of the Global South on the European and North American water companies (2005: 221-71). Assessing the transformative consequences of development schemes (rather than only accounting for their "side effects") accounts for the concrete role of resistance in countering their negative consequences.

\section{Resistance to Neoliberal Development Projects}

In order to understand the sources and nature of resistance in the age of late capitalism, one should begin with the question of why there is widespread resistance to development schemes. As noted above with reference to Levien's comparison of regimes of dispossession in post-colonial India, dispossession serving national developmentalist goals such as industrialization had a higher degree of popular legitimacy compared to neoliberal dispossession, whose developmentalist promise is weak. By visiting the discussion between Arturo Escobar and Thayer Scudder over the actual meaning of "development," Marc Edelman makes a related point:

But do Scudder and Escobar intend the same thing when they say "development"? Certainly not. Scudder clearly means something like "improved well-being" or "rising living standards." For Escobar, on the other hand, "development" signifies a destructive discourse and its associated institutional manifestations. Having assigned this negative meaning to the term, he rightly questions whether people want it. But it 
hardly follows that "the large majority of the world's population" does not desire improved well-being. Indeed, poor people's opposition to development projects is usually rooted in their perception, too frequently well founded, that such schemes threaten their living standards (whether economically or culturally defined). Escobar would likely agree. But is this evidence of opposition to development, as he claims? Only in a world in which idiosyncratic understandings of everyday words and rhetorical sleight-of-hand substitute for empirical investigation and reasoned argument (Edelman, 1999: 10).

Ferguson and Goldman give many examples supporting Edelman's argument. In his chapter on livestock development, Ferguson explains how the establishment of grazing associations in Lesotho threatened stockowners. $\mathrm{He}$ writes, "the result of the grazing association was for them a net loss of 1,500 hectares of good grazing land to which they had previously had customary rights. In the time of scarce grazing, such a net loss was not inconsiderable" (Ferguson, 1990: 173). Peasants countered this attempt by cutting fences around enclosures and reclaiming their grazing land, thereby violating the association's monopoly over grazing (1990: 172). Similarly, after the foundation of The Basotho Pony Project, funded by the government of Ireland, "land was alienated from local farmers to make room for the Pony Project. Shortly after the new project had been started, unknown parties broke into the fenced pastures, took the entire herd of ponies, and, using dogs, drove them all off a precipice to their deaths. This was perhaps the most dramatic manifestation of a deep-felt resentment" (1990: 244).

In line with Edelman, Goldman draws parallels between "development" and global capitalism: "Crippling debt, rising income inequalities, and exclusion from such basic goods as fertile land, health care, and clean water are as much the result of the development as they are attributable to the fundamental inequalities built into the global political economy" (Goldman, 2005: xii). Moreover, he criticizes environmental NGOs for their role in the creation of "green neoliberalism," which does no more, he argues, than forcefully deepen the process of "accumulation by dispossession." In line with this criticism, he tends to focus on resistance movements that are relatively independent from capitalism, international development institutions, and the national state. $\mathrm{He}$ looks at resistance to the privatization of water and other natural resources; international campaigns against the Third World debt; and mass protests in the summits of the World Bank, IMF, and the World Trade Organization; in addition to predicting how these movements might reverse the process of dispossession. Goldman concludes on an optimistic note: "Another world is indeed possible" (2005: 290).

Harvey (2003: 172) stresses the need for an alliance of workers' 
movements and popular struggles against dispossession and identifies historical obstacles to making another word possible:

But the intense difficulty of sustaining expanded reproduction was also generating a much greater emphasis upon a politics of accumulation by dispossession. The forms of organization developed to combat the former did not translate well when it came to combating the latter. Generalizing crudely, the forms of left-wing political organization established in the period 1945-73, when expanded reproduction was in the ascendant, were inappropriate to the post-1973 world, where accumulation by dispossession moved to the fore as the primary contradiction within the imperialist organization of capital accumulation.

Nevertheless, unlike peasants' resistance to various dispossessory attempts at earlier periods, those struggling against dispossession today mostly consist of semi-proletarians who earn part of their living through wage labor. For this reason, there seems to be no great difference between the semi-proletarianized "workers resisting their full proletarianization" through anti-dispossession struggles and the movements of full proletarians for higher wages and better working conditions (Glassman, 2006: 615). In this respect, Geoff Bailey's (20142015) reformulation of the question of political alliance is noteworthy:

But in the way [Harvey has] framed the theory, it appears that you have fights against dispossession on one side and fights at the point of production on the other. It is unclear how that chasm can be bridged beyond moral or intellectual appeals to solidarity and the abstract ways in which both struggles are the product of the same system [...] There is also a long history within the revolutionary Marxist tradition of thinking about working class struggle not as something limited to the workplace or counterposed to the wider struggles of oppressed and exploited peoples, but as something central to them, whether it is Marx's writings on the working class role in the struggle for democracy in the 1848 revolutions, or Lenin's writings about the relationship between working class struggle and the struggles of the Russian peasantry, Trotsky's writings on permanent revolution, or Antonio Gramsci's writings on the "southern question" in Italy.

Bailey's point is certainly invaluable, but as he also admits, the construction of such an alliance remains to be a formidable challenge.

\section{Conclusion}

Based on a review of the existing literature on development policy, neoliberalism, and accumulation by dispossession, this article makes four related points regarding the dispossessory effects of development projects in the neoliberal era. First, it redefines "accumulation by dispossession" as the state's 
transfer of lower-class people's small-scale private property or common property (over land and other resources) to capital through extra-economic and/or economic coercion. Second, it suggests that while productive concerns such as industrialization and infrastructure construction shaped the politics of dispossession in the era of national developmentalism, the link between production and dispossession weakened in the neoliberal era. In other words, capital often needs the land and resources of lower-class people but, due to rapid advances in labor-saving technology and the increasing significance of the real estate sector, does not have a similar desire to exploit their labor. Third, international institutions often dismiss the political nature of economic backwardness and poverty by redefining them as essentially technical questions whose solutions require expertise rather than political action. This discourse aims to naturalize and legitimize dispossession. Finally, this paper stresses the immense potentials of and formidable challenges to constructing alliances of semi-proletarians struggling against dispossession and full proletarians struggling against exploitation.

\section{References}

Anievas, Alexander and Kerem Nişancıoğlu. (2015), How the West Came to Rule: The Geopolitical Origins of Capitalism (London: Pluto Press).

Ashman, Sam and Alex Callinicos. (2006), "Capital Accumulation and the State System: Assessing David Harvey's The New Imperialism", Historical Materialism 14 (4): 107-131.

Bailey, Geoff. (2014-2015), "Accumulation by Dispossession: A Critical Assessment", International Socialist Review 95 https://isreview.org/issue/95/accumulation-dispossession

Batou, Jean. (2015), "Accumulation by Dispossession and Anti-Capitalist Struggles: A Long Historical Perspective", Science \& Society 79 (1): 11-37.

Brenner, Robert. (2006), "What Is, and What Is Not, Imperialism”, Historical Materialism 14 (4): 79-105.

Dorlach, Tim. (2015), "The Prospects of Egalitarian Capitalism in the Global South: Turkish Social Neoliberalism in Comparative Perspective", Economy and Society 44 (4): 519-544.

Easterly, William. (2001), "The Lost Decades: Developing Countries' Stagnation in Spite of Policy Reform 1980-1998", Journal of Economic Growth 6 (2): 135-157.

Edelman, Marc. (1999), Peasants Against Globalization: Rural Social Movements in Costa Rica (Stanford: Stanford University Press).

Elliott, Larry and Heather Stewart. (2017), "IMF: Higher Taxes for Rich Will Cut Inequality Without Hitting Growth", The Guardian, October 11.

Elyachar, Julia. (2005), Markets of Dispossession: NGOs, Economic Development, and the State in Cairo (Durham: Duke University Press).

Ferguson, James. (1990), The Anti-Politics Machine: "Development," "Depoliticization," and Bureaucratic Power in Lesotho (Minneapolis: University of Minnesota Press).

Fischer, Stanley. (2003), "Globalization and Its Challenges", American Economic Review 93 (2): 1-30. 
Glassman, Jim. (2006), "Primitive Accumulation, Accumulation by Dispossession, Accumulation by 'Extra-Economic' Means", Progress in Human Geography 30 (5): 608-625.

Goldman, Michael. (2005), Imperial Nature: The World Bank and Struggles for Social Justice in the Age of Globalization (New Haven: Yale University Press).

Güven, Ali Burak. (2016), "Rethinking Development Space in Emerging Countries: Turkey's Conservative Movement", Development and Change 47 (5): 995-1024.

Güven, Ali Burak. (2018), "Whither the Post-Washington Consensus? International Financial Institutions and Development Policy Before and After the Crisis", Review of International Political Economy 25 (3): 392-417.

Hall, Derek. (2013), "Primitive Accumulation, Accumulation by Dispossession and the Global Land Grab", Third World Quarterly 34 (9): 1582-1604

Harootunian, Harry. (2000), Overcome by Modernity: History, Culture, and Community in Interwar Japan (Princeton: Princeton University Press).

Harootunian, Harry. (2004), The Empire's New Clothes: Paradigm Lost, and Regained (Chicago: Prickly Paradigm Press).

Harvey, David. (2003), The New Imperialism (Oxford: Oxford University Press).

Harvey, David. (2005), A Brief History of Neoliberalism (Oxford: Oxford University Press).

Harvey, David. (2006), "Comment on Commentaries", Historical Materialism 14 (4): 157-166.

Levien, Michael. (2012), "The Land Question: Special Economic Zones and the Political Economy of Dispossession in India", The Journal of Peasant Studies, 39 (3-4): 933-969.

Levien, Michael. (2013), "The Politics of Dispossession: Theorizing India's 'Land Wars”, Politics \& Society 41 (3): 351-394.

Li, Tania Murray. (2011), "Centering Labor in the Land Grab Debate", The Journal of Peasant Studies 38 (2): 281-298.

Marx, Karl. ([1867] 1976), Capital: A Critique of Political Economy, Volume 1, translated by Ben Fowkes (London and New York: Penguin Books).

Obinger, Herbert and Carina Schmitt. (2011), "Guns and Butter? Regime Competition and Welfare State During the Cold War", World Politics 63 (2): 246-270.

Öniş, Ziya (2012), "The Triumph of Conservative Globalism: The Political Economy of the AKP Era”, Turkish Studies 13 (2): 135-152.

Öniş, Ziya and Fikret Şenses. (2005), "Rethinking the Emerging Post-Washington Consensus", Development and Change 36 (2): 263-290.

Rist, Gilbert. ([1997] 2008), The History of Development: From Western Origins to Global Faith, translated by Patrick Camiller (London and New York: Zed Books).

Sassen, Saskia. (2010), "A Savage Sorting of Winners of Losers: Contemporary Versions of Primitive Accumulation", Globalizations 7 (1): 23-50.

Stiglitz, Joseph. (1998), "More Instruments and Broader Goals: Moving Toward the Post-Washington Consensus", WIDER Annual Lecture, Helsinki, January 7.

Trotsky, Leon. ([1932] 2008), History of the Russian Revolution, translated by Max Eastman (Chicago: Haymarket Books).

Van der Linden, Marcel. (2007), "The 'Law' of Uneven and Combined Development: Some Underdeveloped Thoughts", Historical Materialism 15 (1): 145-165.

Van Gils, Eske and Erdem Yörük. (2017), "The World Bank's Social Assistance Recommendations for Developing and Transition Economies: Containment of Political Unrest and Mobilization of Political Support", Current Sociology 65 (1): 113-132.

Vijayabaskar, M. and Ajit Menon. (2018), "Dispossession by Neglect: Agricultural Land Sales in Southern India”, Journal of Agrarian Change 18 (3): 571-587. 